\title{
AKRUAL
}

Jurnal Akuntansi

http://journal.unesa.ac.id/index.php/aj

\section{ANALISIS PERHITUNGAN BIAYA SATUAN (UNIT COST) SPP \\ BULANAN PROGRAM REGULER DAN PREMIUM DI SEKOLAH BOLA BASKET (SBB) DBL ACADEMY SURABAYA PADA TAHUN 2017}

\author{
Ahmad Saddam Husni \\ Program Studi Akuntansi Universitas Negeri Surabaya \\ a.saddamhusni@gmail.com
}

\begin{abstract}
Abstrak
Penelitian ini dilakukan bertujuan untuk menambah pengetahuan mengenai penentuan tarif pelayanan dengan menggunakan metode Activity Based Costing dan dapat dijadikan sebagai acuan dalam menetapkan tarif SPP Bulanan pada Sekolah Bola Basket DBL Academy. Penelitian ini juga digunakan sebagai pembanding antara penggunaan metode Activity Based Costing dengan metode penentuan tarif yang sudah ada. Metode analisis yang digunakan adalah studi kasus, karena dengan menggunakan studi kasus akan mampu member gambaran yang mendalam tentang bagaimana penentuan tarif SPP Bulanan dengan menggunakan Activity Based Costing pada Sekolah Bola Basket DBL Academy. Hasil dari penelitian ini menunjukkan bahwa dari perhitungan tarif SPP Bulanan menggunakan Activity Based Costing apabila dibandingkan dengan tarif yang sudah ada, maka Activity Based Costing memberikan hasil yang lebih kecil untuk program regular dan premium. Perbedaan tarif ini terjadi karena pembebanan biaya overhead pada masing-masing produk. Pada perhitungan akuntansi biaya tradisional, biaya overhead pada masing-masing produk dibebankan hanya menggunakan satu cost driver saja.
\end{abstract}

K ata Kunci: Activity Based Costing, Sekolah Bola Basket, Penentuan Tarif

\section{PENDAHULUAN}

Dalam era globalisasi dan ditunjang perkembangan dunia usaha yang semakin pesat mengakibatkan naiknya persaingan bisnis. Persaingan tidak hanya muncul pada perusahaan yang baru berdiri, perusahaan yang sudah lama berdiri pun pasti merasakan persaingan juga. Setiap perusahan akan beradu strategi bisnis. Untuk menghadapi persaingan tersebut dibutuhkan manajemen yang handal dan mampu mengantisipasi persaingan dan bisa menjalankan perusahaan yang efektif dan efisien. Persaingan tersebut tidak hanya terjadi dalam perusahaan yang bergerak di bidang manufaktur, tetapi juga perusahaan di bidang jasa. Salah satu perusahaan jasa adalah pendidikan olahraga (Najah, 2016).

Sekolah Bola Basket (SBB) merupakan salah satu contoh pendidikan olahraga. Di klub profesional bola basket di Indonesia seperti Satria Muda Jakarta, Garuda Bandung, Satya Wacana Salatiga, dan CLS Knights Surabaya tentunya memiliki sekolah bola 
basketnya masing-masing. Sekolah bola basket (SBB) ini jelas diperuntukkan untuk anakanak dan remaja yang ingin belajar dan berlatih bola basket dengan baik dan benar dengan bimbingan pelatih yang berpengalaman. Salah satu SBB yang mendapatkan perhatian lebih oleh pecinta bola basket di tanah air adalah lahirnya DBL Academy di Bulan Januari 2016.

DBL Academy merupakan salah satu Sekolah Bola Basket (SBB) terbesar di Surabaya. Sekolah basket ini dikelola oleh PT. DBL Indonesia yang telah terkenal akan liga basket pelajar terbesar se-Indonesianya, yaitu Liga Developmental Basketball League (DBL) dan Liga Junior Basketball League (JRBL). Tentunya hal ini akan berdampak langsung dalam pengelolaan sekolah bola basket ini. SBB DBL Academy ini memang tergolong baru, didirikan pada bulan januari tahun 2016, namun sekolah ini mendapatkan respon positif dari masyarakat. Terbukti dengan banyaknya peserta didik yang mencapai ratusan siswa.

Untuk menerapkan praktik bisnis yang sehat berdasarkan kaidah manajemen yang baik dalam rangka memberikan layanan yang bermutu dan berkesinambungan, serta dikelola secara profesional, maka dalam penyelenggaraannya membutuhkan informasi yang tepat dan akurat. Salah satu informasi yang dibutuhkan adalah informasi tentang biaya harga pokok dalam penentuan tarif pelayanan dalam waktu tertentu.

Tarif pelayanan adalah sebagian atau seluruh biaya penyelenggaraan kegiatan pelayanan di Sekolah Bola Basket (SBB) yang dibebankan kepada masyarakat sebagai imbalan atas jasa pelayanan yang diterima. Dalam keadaan normal tarif harus menutup biaya penuh yang diterkait dengan biaya operasional harian dan persentase keinginan laba yang diinginkan. Salah satu sumber pendapatan SBB adalah tarif SPP Bulanan. Penentuan tarif SPP Bulanan merupakan keputusan yang sangat penting karena dapat mempengaruhi kinerja perusahaan secara jangka panjang.

Penentuan tarif pelayanan pada perusahaan jasa secara akurat merupakan hal yang mudah apabila perusahaan memproduksi sedikit produk. Jika perusahaan memiliki jumlah produk yang banyak untuk ditawarkan dan produk tersebut menggunakan jumlah yang berbeda-beda, maka akan lebih sulit menemukan tarif pelayanan yang akurat.

Selama ini manajemen SBB DBL Academy menghitung tarif SPP peserta didik disetiap bulannya menggunakan perhitungan biaya tradisional. Perhitungan biaya tradisional ini dilakukan untuk program regular dan premium. Dalam perhitungan penentuan tarif SPP Bulanan tersebut adalah dengan menjumlahkan semua biaya yang dikeluarkan untuk produk ditambah dengan persentase profit yang ditentukan oleh 
manajemen. Hal ini tentunya akan mengakibatkan distorsi biaya atau kesalahan dalam pembebanan biaya atas produk jasa yang dihasilkan oleh SBB DBL Academy.

Kelemahan sistem penentuan tarif tersebut dapat diperbaiki melalui penerapan sistem penentuan tarif berdasarkan aktivitas atau yang lebih dikenal dengan metode Activity Based Costing ( $A B C)$. ABC menggunakan aktivitas sebagai basis penggolongan biaya untuk menghasilkan biaya aktivitas dan informasi biaya yang lebih akurat, sehingga ABC sangat tepat diterapkan pada perusahaan dengan keanekaragaman produk seperti pada Sekolah Bola Basket (SBB).

Menurut Kamarudin (2013 : 13), “ABC sebagai suatu proses yang menghitung biaya objek, seperti produk, jasa, dan pelanggan". Perhitungan biaya konsumsi dari masing-masing aktivitas yang ada harus tepat, sehingga perusahaan dapat menentukan harga yang kompetitif di pasar global seperti saat ini.

Pada perhitungan akuntansi dengan metode tradisional, biaya overhead pada masing-masing produk dibebankan hanya menggunakan satu cost driver saja. Dalam perhitungan dengan metode $\mathrm{ABC}$, biaya aktivitas dialokasikan pada setiap cost driver secara tepat berdasarkan konsumsi dari masing-masing aktivitas tersebut. Penggunaan perhitungan metode $\mathrm{ABC}$ memiliki keakuratan yang lebih baik dan tepat. Metode $\mathrm{ABC}$ dapat meningkatkan ketelitian dalam perincian biaya dan ketepatan pembiayaan yang lebih akurat, serta dapat membantu perusahaan jasa dalam menjalankan kegiatan operasionalnya secara efektif dan efisien.

Penerapan ABC diharapkan mampu memberikan perhitungan tarif biaya SPP per bulan untuk siswa didik regular maupun premium yang akurat, karena biaya setiap aktivitasnya dapat dibebankan dengan akurat sehingga dapat mudah ditelusuri. Dalam penerapannya, $\mathrm{ABC}$ dapat memberikan informasi mengenai penggunaan aktivitas secara detail sehingga manajemen nantinya dapat menganalisis dan mengambil keputusan dengan dasar yang lebih baik. Berdasarkan uraian yang terdapat pada latar belakang masalah, dapat dirumuskan pertanyaan penelitian sebagai berikut, berapakah harga satuan yang sebenarnya untuk menetapkan SPP bulanan di program kelas reguler dan premium di Sekolah Bola Basket (SBB) DBL Academy agar dapat bersaing dengan Sekolah Bola Basket lainnya yang berada di Surabaya?

Sesuai dengan pertanyaan penelitian di atas, penulis mengharapkan akan mendapatkan hasil dari tujuan penelitian ini, untuk mengetahui harga satuan yang sebenarnya dalam menetapkan SPP bulanan di program kelas reguler dan premium di Sekolah Bola Basket (SBB) DBL Academy agar dapat bersaing dengan Sekolah Bola 
Basket lainnya yang berada di Surabaya. Dengan adanya keunggulan ABC dengan akuntansi biaya tradisional seperti yang dijelaskan dalam latar belakang diatas, maka peneliti melakaukan penelitian dengan judul "Analisis Perhitungan Biaya Satuan (Unit Cost) SPP Bulanan Program Reguler dan Premium di Sekolah Bola Basket (SBB) DBL Academy Surabaya tahun 2017”.

\section{KAJIAN PUSTAKA}

Beberapa peneliti sebelumnya berpendapat bahwa penerapan metode Activity Based Costing memiliki perbedaan dengan penerapan metode perhitungan secara tradisional. Sari (2017) melakukan penelitian dengan judul Penerapan Metode Activity Based Costing dalam menentukan harga pokok kamar hotel pada Hotel Grand Kartika Pontianak. Hasil penelitian menunjukkan bahwa pengalokasian biaya aktifitas ke setiap kamar memberikan hasil yang lebih akurat dan tepat dibandingkan dengan penggunaan biaya yang telah ditetapkan oleh pihak hotel menggunakan sistem tradisional.

Puspitawati (2014) melakukan penelitian dengan judul analisis kinerja kemandirian keuangan dan aktivitas layanan rawat inap utama pada badan layanan umum daerah rumah sakit jiwa Menur dengan metode ABC. Penelitian ini bertujuan untuk membandingkan tarif jasa rawat inap di rumah sakit jiwa Menur dengan menggunakan biaya tradisional dengan menggunakan ABC. Hasil penelitian menunjukkan bahwa pengalokasian biaya aktifitas ke setiap kamar memberikan hasil yang lebih akurat dan tepat.

Najah (2016) melakukan penelitian dengan judul penerapan metode $A B C$ dalam menentukan tarif jasa rawat inap (studi kasus pada Rumah Sakit Umum RA. Kartini Kab. Jepara). Penelitian ini bertujuan untuk membandingkan tarif jasa rawat inap di Rumah Sakit Umum RA. Kartini dengan menggunakan unit cost dengan menggunakan ABC. Hasil penelitian adalah menunjukkan bahwa metode $\mathrm{ABC}$ lebih akurat dalam penerapannya karena mampu mengalokasikan biaya aktifitas ke setiap kamar berdasarkan konsumsi masing-masing aktifitas.

\section{Konsep Akuntansi Biaya}

Biaya menurut Hansen dan Mowen (2009: 40), merupakan suatu sumber yang dikorbankan (sacrifice) atau dilepaskan (forgone) untuk mencapai tujuan tertentu dan pengorbanan tersebut hanya bisa diukur apabila sudah dikonversikan ke dalam nilai uang. Menurut Carter (2009 : 30) pengertian biaya adalah suatu nilai tukar, pengeluaran, atau 
pengorbanan yang dilakukan untuk menjamin perolehan manfaat yang di cerminkan sebagai penyusutan atas arus kas atau asset lainnya.

Semua biaya atau beban yang dikeluarkan untuk memperoleh atau memberi manfaat merupakan pengorbanan sumber daya ekonomi suatu perusahaan. Istilah biaya atau beban dalam hal ini memiliki pengertian yang sama ketika pengorbanan sumber daya ekonomi perusahaan yang telah memberi manfaat, yang perlu diperhatikan dalam pencatatan menggunakan istilah biaya atau beban, harus terdapat konsistensi dari periode ke periode dalam pelaporan akuntansi (Masiyah dan Yuningsih, 2009 : 17).

Menurut Firdaus dan Wasilah (2009 : 4) "akuntansi biaya adalah bagian dari akuntansi manajemen dimana merupakan salah satu dari bidang khusus akuntansi yang menekankan pada penentuan dan pengendalian biaya". Akuntansi biaya menyediakan informasi yang dibutuhkan oleh akuntansi keuangan dan akuntansi manajemen. Akuntansi biaya mengukur dan melaporkan setiap informasi keuangan dan non keuangan yang terkait dengan biaya perolehan atau pemanfaatan sumber daya dalam suatu organisasi.

\section{Klasifikasi Biaya}

Dalam akuntansi biaya, biaya dapat diklasifikasikan dengan berbagai cara. Tujuan klasifikasi biaya dapat menempatkan penentuan biaya yang berbeda. Menurut Mulyadi (2010 : 13-16) penggolongan atau pengklasifikasian biaya dapat dilakukan berdasarkan, a) objek pengeluaran, b) fungsi di dalam perusahaan, c) hubungan biaya dengan produk yang dibiayai, d) penggolongan biaya menurut perilakunya dalam hubungannya dengan perubahan volume kegiatan, e) penggolongan biaya atas dasar jangka waktu manfaatnya.

\section{Activity Based Costing System (ABC)}

Activity based costing pada dasarnya merupakan penentuan harga pokok produk atau jasa secara cermat bagi keputusan manajemen secara cermat pula konsumsi sumber daya dalam setiap aktifitas yang digunakan untuk menghasilkan produk atau jasa, Mulyadi (2010 : 47). Sedangkan menurut Garrison dan Norren (2006 : 440) yang memiliki pendapat bahwa perhitungan biaya berdasarkan $\mathrm{ABC}$ - adalah metode perhitungan biaya (costing) yang dirancang untuk menyediakan informasi biaya bagi manager untuk keputusan strategi dan keputusan lainnya yang mungkin akan mempengaruhi kapasitas dan biaya tetap. Berdasarkan kedua pendapat tersebut, $\mathrm{ABC}$ merupakan prosedur akuntansi untuk menghitung biaya berdasarkan aktifitas-aktifitas yang terjadi di dalam perusahaan lalu membebankan biaya tersebut kedalam produk atau jasa untuk 
menghasilkan perhitungan harga pokok yang lebih akurat dan memberikan informasi kepada manajer dalam pengambilan keputusan yang cermat.

\section{Konsep Dasar Activity Based Costing}

Activity Based Costing adalah suatu sistem akuntansi yang lebih memfokuskan pada aktifitas-aktifitas yang terjadi untuk menghasilkan produk atau jasa. Metode ini menyediakan informasi-informasi yang berkaitan dengan aktifitas-aktifitas dan sumber daya yang dibutuhkan untuk melaksanakan aktifitas tersebut.

Menurut Hansen dan Mowen (2009 : 393), terdapat dua dimensi dalam activity based costing, yaitu :a) dimensi biaya (cost dimension), menyediakan informasi biaya mengenai sumber daya, aktifitas-aktifitas, produk dan pelanggan (dari objek biaya lainnya yang mungkin menjadi perhatian perusahaan), b) dimensi proses (proses dimension), menyediakan informasi mengenai aktifitas apa yang dilakukan, mengapa dan sebaik apa aktifitas tersebut dilakukan. Dimensi ini memungkinkan perusahaan melakukan peningkatan-peningkatan kinerja yang berkesinambungan dengan mengukur hasilnya secara rutin.

\section{Manfaat dan Keterbatasan Activity Based Costing}

Dalam penerapannya, metode $\mathrm{ABC}$ memberikan banyak keunggulan daripada metode tradisional. Selain menyajikan informasi yang lebih akurat, metode $\mathrm{ABC}$ juga dapat memberikan informasi yang cermat kepada manajer dalam mengambil keputusan. Dari situ tentu akan memungkinkan manajer ataupun manajemen untuk melakukan perbaikan terus menerus bahkan meningkatkan mutu produk atau jasa dengan tetap berfokus pada penggunaan biaya secara tepat. Manfaat dari penerapan ABC menurut Hansen dan Mowen (2009 : 232), adalah sebagai berikut : a) menyajikan biaya produk lebih akurat dan informatif, yang mengarahkan pengukuran profitabilitas produk lebih akurat terhadap keputusan strategis, tentang harga jual, lini produk, pasar, dan pengeluaran modal, b) pengukuran yang lebih akurat tentang biaya yang dipicu oleh aktifitas, sehingga membantu manajemen meningkatkan nilai produk (product value) dan nilai proses (process value), c) memudahkan memberikan informasi tentang biaya relevan untuk pengambilan keputusan.

Selain manfaat diatas, juga dijelaskan tentang kelemahan penggunaan metode $\mathrm{ABC}$ ini, yaitu: a) Alokasi, beberapa biaya dialokasikan secara sembarangan, karena sulitnya menemukan aktivitas biaya tersebut. Contoh: pembersihan pabrik dan pengelolaan proses produksi. b) Biaya-biaya tertentu yang seharusnya berhubungan dengan hasil produk diabaikan begitu saja dalam pengukurannya. Contohnya : biaya iklan, riset, 
pengembangan dan sebagainya. c) Pengeluaran dan waktu yang dikonsumsi. Selain memerlukan biaya yang mahal juga memerlukan waktu yang cukup lama.

\section{Prosedur dalam Penerapan Activity Based Costing}

Prosedur-prosedur yang diperlukan dalam penerapan ABC menurut Simamora (2002 : 292-306) yaitu: 1) Prosedur tahap pertama yaitu penentuan harga pokok berdasarkan aktivitas meliputi empat langkah sebagai berikut : a) penggolongan berbagai aktifitas, b) menghubungkan biaya dengan aktifitas, c) menentuan kelompok biaya (cost pools) yang homogeny, d) penentuan tarif kelompok (pool rate). 2) Prosedur tahap kedua yaitu biayabiaya dari setiap overhead pool ditelusuri kembali ke hasil produksi. Ini dilakukan dengan menggunakan pool rates yang dihitung dalam tahap pertama dan dengan mengukur jumlah sumber-sumber yang digunakan oleh setiap hasil produksi. Biaya overhead yang dibebankan didapatkan atas tarif kelompok dikalikan unit cost yang digunakan. Pengukuran ini hanyalah jumlah dari activity driver yang digunakan oleh setiap hasil produksi.

\section{Cost Driver}

Menurut Warindrani (2006 : 28) pengertian cost driver atau pemicu biaya adalah dasar alokasi yang digunakan dalam $\mathrm{ABC}$ yang merupakan faktor-faktor yang menetukan seberapa besar atau seberapa banyak usaha dan beban kerja yang dibutuhkan untuk melakukan suatu aktivitas. Landasan penting untuk menghitung biaya berdasarkan aktivitas adalah dengan mengidentifikasi penyebab timbulnya biaya atau cost driver untuk setiap aktivitas yang berapa dalam produk tersebut.

\section{METODE PENELITIAN}

Pendekatan penelitian yang dilakukan oleh penulis adalah pendekatan deskriptif kualitatif. Penelitian kualitatif adalah penelitian yang bemaksud untuk memahami fenomena yang dialami oleh subyek penelitian, misalnya perilaku, presepsi, motivasi, dan lain-lain secara holistik, dan dengan cara deskripsi dalam bentuk kata-kata dan bahasa, pada suatu konteks khusus yang alamiah dan dengan memanfaatkan berbagai metode alamiah (Sugiyono, 2011 : 14). Subjek penelitian merupakan sumber data yang dimintai informasinya sesuai dengan masalah penelitian. Moleong (2009 : 56), mendeskripsikan bahwa subjek penelitian bisa disebut sebagai informan, yaitu orang yang dimanfaatkan untuk memberikan informasi tentang situasi dan kondisi latar penelitian.

Objek penelitian ini adalah Sekolah Bola Basket (SBB) DBL Academy yang merupakan anak usaha dari PT. Deteksi Bola basket Lintas (DBL) Indonesia yang berada 
di Gedung Graha Pena, Jalan Ahmad Yani no 88 Surabaya. Tepatnya SBB DBL Academy ini berada di lantai 2 gedung Graha Pena.

Penelitian ini menggunakan sumber data primer dan data sekunder. Menurut Sugiyono (2011 : 225), mendiskripsikan teknik pengumpulan data sebagai langkah yang paling strategis dalam penelitian karena tujuan utama penelitian, terutama pada penelitian kualitatif yang pengumpulan datanya dilakukan pada natural setting dan lebih banyak observasi yang berperan, wawancara mendalam dan dokumentasi.

Teknik analisis data merupakan proses pemilihan, pemusatan perhatian pada penyederhanaan, pengabstrakan dan transformasi data asli yang muncul dari catatancatatan tertulis di lapangan dan berlangsung selama penelitian berlangsung. Langkahlangkah yang diambil dalam proses tehnik analisis data adalah : a) mengidentifikasi aktivitas-aktivitas terkait dengan pelayanan program regular dan premium, b) mengklasifikasikan biaya berdasarkan aktivitas ke dalam berbagai aktivitas, c) mengidentifikasikan cost driver, d)menetukan tarif per unit, e) membebankan biaya produk dengan menggunakan tarif cost driver dan ukuran aktivitas, f) melakukan perbandingan antara perhitungan tarif pelayanan program regular dan premium dengan tarif pelayanan yang sudah diberlakukan selama ini.

\section{HASIL PENELITIAN}

Dalam menentukan tarif jasa pelatihan dengan metode $\mathrm{ABC}$, data-data yang dibutuhkan antara lain adalah data lama hari peserta didik berlatih dan data banyaknya jumlah peserta didik. Pada data yang diperoleh pada bulan Januari tahun 2017, jumlah waktu pelatihan peserta didik untuk program regular adalah selama 289 jam, dan untuk program premium selama 39 jam. Untuk data jumlah peserta didik di waktu yang sama menunjukkan program regular berjumlah 180 siswa, dan program premium berjumlah 9 siswa.

Tabel 1. Lama Waktu pelatihan Peserta Didik DBL Academy Tahun 2017

\begin{tabular}{ccc}
\hline \multicolumn{1}{c}{ Bulan } & Program Reguler & Program Premium \\
\hline Januari & 289 & 39 \\
JUMLAH & $\mathbf{2 8 9}$ & $\mathbf{3 9}$ \\
\hline
\end{tabular}

Sumber : Data SBB DBL Academy 
Tabel 2. Jumlah Peserta Didik SBB DBL Academy Tahun 2017

\begin{tabular}{ccc}
\hline \multicolumn{1}{c}{ Bulan } & Program Reguler & Program Premium \\
\hline Januari & 180 & 9 \\
JUMLAH & $\mathbf{1 8 0}$ & $\mathbf{9}$ \\
\hline
\end{tabular}

Sumber : Data SBB DBL Academy

Aktivitas-aktivitas yang ada pada Sekolah Bola Basket DBL Academy terkait dengan pelayanan pelatihan fundamental bola basket dapat diidentifikan sebagaimana berikut : a) aktivitas pelayanan administrasi umum, b) aktivitas apparel peserta didik, c) aktivitas latihan harian, d) aktivitas character building dan kelas nutrisi, e) aktivitas biaya listrik dan air, f) aktivitas cleaning service, g) aktivitas konsumsi, h) aktivitas sewa bangunan, i) aktivitas pemeliharan fasilitas latihan dan fitness.

Tabel 3. Identifikasi Aktivitas Biaya ke dalam Berbagai Aktivitas

\begin{tabular}{clc}
\hline No. & \multicolumn{1}{c}{ Aktivitas } & \multicolumn{1}{c}{ Kelompok Aktivitas } \\
\hline 1. & Aktivitas Pelayanan Administrasi Umum & Batch level activity costing \\
2. & Aktivitas Apparel Peserta Didik & Unit level activity costing \\
3. & Aktifitas Latihan Harian & Unit level activity costing \\
4. & Aktivitas Character Building dan Kelas & Batch level activity costing \\
5. & Nutrisi & Antifitas Biaya Listrik dan Air level activity costing \\
6. & Aktivitas Cleaning Service & Batch level activity costing \\
7. & Aktivitas Konsumsi & Unit level activity costing \\
8. & Aktivitas Sewa Bangunan & Facility level activity costing \\
9. & Aktivitas Pemeliharaan fasilitas & Latihan \\
\end{tabular}

Sumber : Data diolah Penulis

Setelah mengetahui aktivitas-aktivitas yang terdapat di SBB DBL Academy, tahap selanjutnya dalam penelitian ini yakni, dilakukan proses pengidentifikasian biaya-biaya yang timbul atas pengkonsumsian sumber daya saat melakukan aktivitas tersebut. Masing-masing aktivitas dihitung biaya yang dikeluarkan dalam Bulan Januari. 
Tabel 4. Total Biaya Bulan Januari Tahun 2017

\begin{tabular}{clc}
\hline No. & \multicolumn{1}{c}{ Aktivitas } & Total Biaya \\
\hline 1. & Aktivitas Pelayanan Administrasi Umum & 51.449 .749 \\
2. & Aktivitas Apparel Peserta Didik & 5.829 .475 \\
3. & Aktivitas Latihan Harian & 40.320 .000 \\
4. & Aktivitas Character Building dan Kelas Nutrisi & 27.001 .431 \\
5. & Aktivitas Biaya Listrik dan Air & 11.159 .559 \\
6. & Aktivitas Cleaning Service & 5.276 .000 \\
7. & Aktivitas Konsumsi & 3.191 .875 \\
8. & Aktivitas Sewa Bangunan & 40.000 .000 \\
9. & Aktivitas Pemeliharaan fasilitas Latihan dan & \\
& Fitness & \\
\hline
\end{tabular}

Sumber : Data diolah Penulis

Setelah membebankan biaya untuk masing-masing aktivitas, tahap selanjutnya adalah mengidentifikasi pemicu biaya pada masing-masing aktivitas. Pada setiap aktivitas, dilakukan penelusuran apa yang menyebabkan timbulnya biaya.

Tabel 5. Pengelompokkan Cost Driver

\begin{tabular}{|c|c|c|}
\hline No. & Aktivitas & Cost Driver \\
\hline 1. & \multicolumn{2}{|c|}{ Aktivitas Pelayanan Administrasi Umum Jumlah peserta didik } \\
\hline 2. & Aktivitas Apparel Peserta Didik & Jumlah peserta didik \\
\hline 3. & Aktifitas Latihan Harian & Jumlah hari latihan \\
\hline 4. & $\begin{array}{l}\text { Aktivitas Character Building dan Kelas } \\
\text { Nutrisi }\end{array}$ & Jumlah peserta didik \\
\hline 5. & Aktifitas Biaya Listrik dan Air & Jumlah hari latihan \\
\hline 6. & Aktivitas Cleaning Service & Luas bangunan DBL Academy \\
\hline 7. & Aktivitas Konsumsi & Jumlah hari latihan \\
\hline 8. & Aktivitas Sewa Bangunan & Luas bangunan DBL Academy \\
\hline 9. & $\begin{array}{l}\text { Aktivitas Pemeliharaan fasilitas Latihan } \\
\text { dan Fitness }\end{array}$ & Luas bangunan DBL Academy \\
\hline
\end{tabular}

Sumber : Data diolah Penulis

Setelah menentukan pemicu biaya, tahap selanjutnya adalah menentukan kelompok-kelompok biaya yang homogeny. Cost pool merupakan penggabungan beberapa biaya yang memeiliki cost driver yang sama, kemudian dapat dibebankan secara bersama-sama dengan menggunakan satu cost driver saja. 
Tabel 6. Pengelompokkan Cost Pool

\begin{tabular}{clc}
\hline No. & \multicolumn{1}{c}{ Aktivitas } & \multicolumn{1}{c}{ Cost Pool } \\
\hline 1. & Aktivitas Pelayanan Administrasi Umum & \\
2. & Aktivitas Apparel Peserta Didik & Jumlah peserta didik \\
3. & Aktivitas Character Building dan Kelas & \\
& Nutrisi & \\
4. & Aktivitas Latihan Harian & \\
5. & Aktifitas Biaya Listrik dan Air & Jumlah hari latihan \\
6. & Aktivitas Konsumsi & \\
7. & Aktivitas Cleaning Service & \\
8. & Aktivitas Sewa Bangunan & \\
9. & Aktivitas Pemeliharaan fasilitas Latihan & \\
& dan Fitness & \\
\hline
\end{tabular}

Tahapan selanjutnya adalah menentukan tarif kelompok (pool rate). Penentuan tarif per unit ini dilakukan dengan cara membagi biaya aktivitas untuk setiap kelompok biaya selama Bulan Januari tahun 2017 dengan jumlah cost driver untuk setiap kelompok biaya.

Tabel 7. Perhitungan Tarif per Unit

\begin{tabular}{|c|c|c|c|c|c|}
\hline No. & Aktivitas & $\begin{array}{c}\text { Biaya Aktivitas } 1 \\
\text { Bulan }\end{array}$ & Cost & Driver & Tarif per Unit \\
\hline \multirow[t]{3}{*}{1.} & $\begin{array}{ll}\text { Pelayanan } & \text { Administrasi } \\
\text { Umum } & \end{array}$ & 51.449 .749 & & 189 & 272.220 .89 \\
\hline & Program Regulerr & & & 180 & \\
\hline & Program Premium & & & 9 & \\
\hline \multirow[t]{2}{*}{ No. } & Aktivitas & $\begin{array}{l}\text { Biaya Aktivitas } 1 \\
\text { Bulan }\end{array}$ & Cost & Driver & Tarif per Unit \\
\hline & Apparel Peserta Didik & 5.829 .475 & & 189 & $30.834,78$ \\
\hline \multirow[t]{3}{*}{2.} & Program Reguler & & & 180 & \\
\hline & Program Premium & & & 9 & \\
\hline & Latihan Harian & 40.302 .000 & & 328 & $122.871,95$ \\
\hline \multirow[t]{3}{*}{3.} & Program Reguler & & & 289 & \\
\hline & Program Premium & & & 39 & \\
\hline & $\begin{array}{l}\text { Character Building dan Kelas } \\
\text { Nutrisi }\end{array}$ & 27.001 .431 & & 189 & $142.864,71$ \\
\hline
\end{tabular}




\begin{tabular}{|c|c|c|c|c|}
\hline & Program Reguler & & 180 & \\
\hline & Program Premium & & 9 & \\
\hline & Biaya Air dan Listrik & 11.159 .559 & 328 & $34.023,05$ \\
\hline \multirow[t]{3}{*}{5.} & Program Reguler & & 289 & \\
\hline & Program Premium & & 39 & \\
\hline & Cleaning Service & 5.276 .000 & 1522 & $3.466,49$ \\
\hline \multirow[t]{3}{*}{6.} & Program Reguler & & & \\
\hline & Program Premium & & & \\
\hline & Konsumsi & 3.191 .875 & 328 & $9.731,33$ \\
\hline \multirow[t]{3}{*}{7.} & Program Reguler & & 289 & \\
\hline & Program Premium & & 39 & \\
\hline & Sewa Bangunan & 40.000 .000 & 1522 & $26.281,21$ \\
\hline \multirow[t]{3}{*}{8.} & Program Reguler & & & \\
\hline & Program Premium & & & \\
\hline & $\begin{array}{l}\text { Pemeliharaan fasilitas Latihan } \\
\text { dan Fitness }\end{array}$ & 29.200 .000 & 1522 & $19.185,28$ \\
\hline \multirow{2}{*}{9.} & Program Reguler & & & \\
\hline & Program Premium & & & \\
\hline
\end{tabular}

Sumber : Data diolah Penulis

\section{Menghitung Harga Pokok SPP Bulanan}

Setelah tarif per unit cost driver dihitung, selanjutnya tarif pelatihan SBB DBL Academy dapat dihitung dengan beberapa tahapan. Tahapan-tahapan yang dilakukan dalam perhitungan tarif pelatihan ini adalah sebagai berikut : a) menghitung biaya overhead yang dibebankan pada program regular dan program premium dengan cara tarif per unit dikalikan dengan biaya pemicu (cost driver) yang digunakan pada masing-masing program SBB DBL Academy, b) menjumlahkan seluruh biaya-biaya aktivitas yang telah dikelompokkan, c) membagi total biaya-biaya aktivitas pada program regular dan program premium dengan jumlah hari peserta didik tersebut berlatih.

Rincian untuk menghitung harga pokok tarif SPP Bulanan pelatihan SBB DBL Academy pada Program Reguler dan Program Premium dapat dilihat pada tabel 4.8. Sesuai dengan perhitungan tabel tersebut, diketahui tarif SPP Bulanan pelatihan SBB DBL Academy Program Reguler adalah sebesar Rp. 702.070,23. Pada tabel 4.9, diketahui tarif SPP Bulanan pelatihan SBB DBL Academy Program Premium adalah sebesar Rp. 2.179.174,13 
Tabel 8. Perhitungan Tarif SPP Bulanan Program Reguler

\begin{tabular}{|c|c|c|c|c|}
\hline No. & Aktivitas & Tarif per Unit & $\begin{array}{c}\text { Cost } \\
\text { Driver }\end{array}$ & Jumlah \\
\hline 1. & Pelayanan Administrasi Umum & 272.220 .89 & 180 & $48.999 .760,55$ \\
\hline 2. & Apparel Peserta didik & $30.834,78$ & 180 & $5.551 .880,95$ \\
\hline 3. & Aktivitas Latihan Harian & $122.871,95$ & 289 & $35.509 .993,90$ \\
\hline 4. & $\begin{array}{c}\text { Character Building dan Kelas } \\
\text { Nutrisi }\end{array}$ & $142.864,71$ & 180 & $25.715 .648,57$ \\
\hline 5. & Biaya Air dan Listrik & $34.023,05$ & 289 & $9.832 .660,22$ \\
\hline 6. & Cleaning Service & $3.466,49$ & 1522 & $5.276 .000,00$ \\
\hline 7. & Aktivitas Konsumsi & $9.731,33$ & 289 & $2.812 .353,28$ \\
\hline 8. & Sewa Bangunan & $26.281,21$ & 1522 & $40.000 .000,00$ \\
\hline 9. & $\begin{array}{l}\text { Pemeliharaan fasilitas Latihan } \\
\text { dan Fitness }\end{array}$ & $19.185,28$ & 1522 & $29.200 .000,00$ \\
\hline & Total Biaya Aktivitas & & & 202.898.297,87 \\
\hline & Jumlah Jam Latihan & & & 289 \\
\hline & Tarif SPP Bulanan & & & $702.070,23$ \\
\hline
\end{tabular}

Sumber : Data diolah Penulis

Tabel 8. Perhitungan Tarif SPP Bulanan Program Premium

\begin{tabular}{ccccc}
\hline No. & Aktivitas & Tarif per Unit & $\begin{array}{c}\text { Cost } \\
\text { Driver }\end{array}$ & Jumlah \\
\hline 1. & Pelayanan Administrasi Umum & 272.220 .89 & 9 & $2.449 .988,05$ \\
2. & Apparel Peserta didik & $30.834,78$ & 9 & $277.594,05$ \\
3. & Aktivitas Latihan Harian & $122.871,95$ & 39 & $4.792 .006,10$ \\
4. & Character Building dan Kelas & $142.864,71$ & 9 & $1.285 .782,43$ \\
5. & Nutrisi & $34.023,05$ & 39 & $1.326 .898,78$ \\
6. & Cleana Air dan Listrik & $3.466,49$ & 1522 & $5.276 .000,00$ \\
7. & Aktivitas Konsumsi & $9.731,33$ & 39 & $379.521,72$ \\
8. & Sewa Bangunan & $26.281,21$ & 1522 & $40.000 .000,00$ \\
9. & Pemeliharaan fasilitas Latihan & $19.185,28$ & 1522 & $29.200 .000,00$ \\
\hline
\end{tabular}




\begin{tabular}{lc}
\hline dan Fitness & \\
Total Biaya Aktivitas & $84.987 .791,13$ \\
Jumlah Jam Latihan & 39 \\
HPP SPP Bulanan & $2.179 .174,13$ \\
\hline
\end{tabular}

Sumber : Data diolah Penulis

Tabel 10. Perbandingan Tarif SPP Bulanan Pelatihan

\begin{tabular}{ccc}
\hline Program & Tarif SBB DBL Academy & Tarif ABC \\
\hline Program Reguler & Rp. 1.000 .000 & Rp. 702.070,23 \\
Program Premium & Rp. 2.500 .000 & Rp. 2.179.174,13 \\
\hline
\end{tabular}

Sumber : Data diolah Penulis

Berdasarkan perhitungan tabel diatas, bisa dibandingkan perhitungan antara metode tradisional dengan perhitungan metode $\mathrm{ABC}$, terlihat kedua program pelatihan di SBB DBL Academy memberikan hasil yang lebih kecil dibandingkan dengan tarif Bulanan SBB DBL Academy sejak bulan januari tahun 2017. Perbedaan tersebut terjadi karena pembebanan biaya overhead pada masing-masing produk. Pada perhitungan akuntandi dengan metode tradisional, biaya overhead pada masing-masing produk dibebankan hanya menggunakan satu cost driver saja. Dalam perhitungan dengan metode $\mathrm{ABC}$, biaya aktivitas dialokasikan pada setiap cost driver secara tepat berdasarkan konsumsi dari masing-masing aktivitas tersebut. Implementasi metode $\mathrm{ABC}$ dalam penentuan tarif SPP Bulanan di SBB DBL Academy Surabaya sangat cocok diterapkan dalam perhitungan yang memiliki biaya yang lebih tinggi.

\section{KESIMPULAN}

Berdasarkan hasil perhitungan tarif SPP Bulanan SBB DBL Academy pada bab sebelumnya, maka dapat disimpulkan bahwa perhitungan tarif SPP Bulanan program regular dan premium menggunakan $\mathrm{ABC}$ dilakukan melalui dua tahap. Tahap pertama yaitu penelusuran biaya, biaya ditelusuri dari aktivitas-aktivitas yang ada di Sekolah bola basket tersebut terkait pelayanan dan pelatihan. Tahapan yang kedua adalah pembebanan biaya overhead yang dibebankan pada masing-masing program pelatihan.

Dari perhitungan tarif SPP Bulanan program pelatihan menggunakan ABC, apabila dibandingkan dengan tarif pelatihan yang telah ditetapkan oleh pihak manajemen DBL 
Academy menunjukkan bahwa untuk program regular dan program premium mendapatkan hasil yang lebih kecil. Perbedaan tersebut terjadi karena pembebanan biaya overhead pada masing-masing produk. Pada perhitungan akuntansi dengan metode tradisional, biaya overhead pada masing-masing produk dibebankan hanya menggunakan satu cost driver saja. Dalam perhitungan dengan metode $\mathrm{ABC}$, biaya aktivitas dialokasikan pada setiap cost driver secara tepat berdasarkan konsumsi dari masingmasing aktivitas tersebut.

\section{Saran}

Dengan menggunakan ABC, pihak manajemen SBB DBL Academy Surabaya dapat mengendalikan biaya lebih baik dikarenakan pada metode ini, biaya dianalisis lebih rinci sesuai dengan aktivitas dari masing-masing program pelatihan untuk memenuhi kebutuhan pihak manajemen sendiri dalam pengambilan keputusan, baik yang bersifat strategik maupun dalam hal operasional. Sehingga Pihak SBB DBL Academy bisa menerapkan metode $\mathrm{ABC}$ ini sebagai bagian dasar dalam penetuan tarif SPP Bulannya. 


\section{Daftar Pustaka}

Carter, K. William. 2009. Akuntansi Biaya (Cost Accounting). Buku Satu Edisi Empatbelas. Jakarta: Salemba Empat.

Firdaus, A Dunia dan Abdullah Wasilah. 2009. Akuntansi Biaya. Jakarta: Salemba Empat.

Garrison RH, Noreen EW, Brewew PC. 2006. Akuntansi Manajerial. Jakarta: Salemba Empat.

Hansen, Don R. Maryanne M. Mowen. 2009. Akuntansi Managemen edisi 7. Jakarta: Salemba Empat.

Kamaruddin, A. 2013. Akuntansi Manajemen.Edisi Revisi. Jakarta: Raja Grafindo.

Masiyah, Kholmi dan Yuningsih. 2009. Akuntansi Biaya. Edisi Revisi. Malang: UMM Press.

Moleong, Lexy. 2009. Metodologi Penelitian Kualitatif. Bandung: PT Remaja Rosdakarya

Mulyadi. 2010. Activity Based Costing System. Yogyakarta: UPP STIM YKPN

Najah, Nasikhatun. (2016). Penerapan Metode Activity Based Costing System dalam Menentukan Tarif Jasa Rawat Inap (Studi Kasus pada Rumah Sakit Umum RA. Kartini Kabupaten Jepara). Journal Of Accounting, (2)2, 23-35.

Puspitawati, Dwi Indah. (2014). Analisis Kinerja Kemandirian Keuangan dan Aktivitas Layanan Rawat Inap Utama pada Badan Layanan Umum Daerah Rumah Sakit Jiwa Menur dengan Metode Acivity Based Costing. Jurnal Ilmu Ekonomi \& Manajemen, 10(1), 16-26.

Sari, Vivi Parita. 2017. Penerapan Metode Acivity Based Costing System dalam Penentuan Harga Pokok Kamar Hotel pada Hotel Grand Kartika Pontianak. Jurnal FinAcc, (1)9, 1-12.

Simamora, Henry. 2002. Akuntansi Manajemen, Edisi 2. Yogyakarta: UPP AMP YKPN.

Sugiyono. 2011. Memahami Penelitian Kualitatif. Bandung: CV Alfabeta.

Warindrani, Armila Krisma. 2006. Akuntansi Manajemen. Edisi Pertama. Cetakan Pertama. Yogyakarta: Graha Ilmu. 